\title{
Urinary Excretion of Hydroxylysine and its Glycosides as an Index of Collagen Degradation
}

\author{
Stephen M. Krane, Fred G. Kantrowitz, Michael Byrne, \\ Sheldon R. PinNell, and Frederick R. Singer \\ From the Department of Medicine, Harvard Medical School and Medical Services (Arthritis \\ and Endocrine Units), Massachusetts General Hospital, Boston, Massachusetts 02114
}

A B S T RACT Urinary excretion of hydroxyproline (Hyp) is one index of total collagen degradation, from all sources. Since some of the Hyp released from collagen may be further metabolized before it is excreted, other markers are necessary to measure collagen breakdown. Excretion of the glycosides of hydroxylysine (Hyl), glucosyl galactosyl hydroxylysine (Hyl[GlcGal]), and galactosyl hydroxylysine (Hyl[Gal]), more accurately reflects collagen metabolism since these products occur in specific ratios in different tissue collagens and are themselves metabolized only to a minor degree.

The ratios of total $\mathrm{Hyl} / \mathrm{Hyp}$ and $\mathrm{Hyl}(\mathrm{GlcGal}) / \mathrm{Hyl}$ (Gal) were measured in the urine of normal subjects and of patients with Paget's disease of bone, hyperphosphatasia, and extensive thermal burns. In patients with extensive thermal burns the pattern of urinary $\mathrm{Hyl}$ and its glycosides was consistent with degradation of collagen in dermis and fascia. When bone collagen degradation was dominant, the pattern of urinary metabolites reflected that source. Pagetic bone collagen has an amino acid composition similar to normal bone and $\mathrm{Hyl}(\mathrm{GlcGal}) / \mathrm{Hyl}(\mathrm{Gal})$ of $0.396-0.743$, vs. normal of $0.474 \pm 0.088$. In untreated patients with severe Paget's disease of bone or hyperphosphatasia (urinary Hyp $>2.0 \mu \mathrm{mol} / \mathrm{mg}$ creatinine) urinary $\mathrm{Hyl} / \mathrm{Hyp}$ averaged $0.052 \pm 0.002(0.042 \pm 0.009$ in normal bone) and $\mathrm{Hyl}(\mathrm{GlcGal}) / \mathrm{Hyl}(\mathrm{Gal}) 0.601$ $\pm 0.017(0.47 \pm 0.009$ in normal bone). When bone re-

This is publication no. 724 of the Robert W. Lovett Memorial Group for the Study of Diseases Causing Deformities.

Dr. Kautrowitz' present address is Department of Medicine, Beth Israel Hospital, Boston, Mass. 02215. Dr. Pinnell's present address is Division of Dermatology, Department of Medicine, Duke University Medical Center, Durham, N. C. 27710. Dr. Singer's present address is Department of Medicine, University of Southern California School of Medicine, Los Angeles, Calif. 90033.

Received for publication 4 June 1976 and in revised form 29 December 1976. sorption was decreased sufficiently with calcitonin or disodium etidronate in these patients, both the urinary ratios of $\mathrm{Hyl} / \mathrm{Hyp}$ and $\mathrm{Hyl}(\mathrm{GlcGal}) / \mathrm{Hyl}(\mathrm{Gal})$ rose. In normal subjects treated with calcitonin and excreting relatively little $\mathrm{Hyp}$, the ratio of $\mathrm{Hyl} / \mathrm{Hyp}$ approached 0.7 and $\mathrm{Hyl}(\mathrm{GlycGal}) / \mathrm{Hyl}(\mathrm{Gal})$ approached 3.5. These increased ratios reveal the existence of a source of collagen breakdown other than skin or bone. The first subcomponent of complement, $\mathrm{Cl}_{\mathbf{1}}$, which has collagen-like sequences, relatively high amounts of $\mathrm{Hyl}$, and most of the glycosylated $\mathrm{Hyl}$ as $\mathrm{Hyl}(\mathrm{GlcGal})$, could be the source of these metabolites.

\section{INTRODUCTION}

Collagens contain unique, modified amino acids, the most abundant of which is 4-hydroxyproline (Нyp). ${ }^{1}$ Measurement of urinary excretion of total Hyp (free Hyp plus Hyp-containing peptides) has been used extensively as an index of collagen degradation (1). It is not possible to obtain quantitative estimations of collagen breakdown by this measurement since most of the free Hyp is further metabolized to carbon dioxide and other products not included in the Hyp determination and only a portion appears in the urine. Woessner found that less than $15 \%$ of the Hyp of degraded collagen appears in the urine of the pospartum rat (2). Weiss and Klein (3) determined that when collagen peptides were administered to rats, $75 \%$ were metabolized to respiratory carbon dioxide and $25 \%$ excreted. In their studies of a patient with deficiency in Hyp oxidase (hydroxyprolinemia), Efron et al. (4) found that only $20 \%$ of the urinary Hyp was peptide bound whereas $80 \%$ was free. An additional deficiency in the use of measurement of Hyp excretion to assess

\footnotetext{
${ }^{1}$ Abbreviations used in this paper: EHDP, disodium etidronate; Gal, galactosyl; Hyl, hydroxylysine; Hyp, 4hydroxyproline; $\mathrm{Hyl}(\mathrm{Gal}), \beta$-l-galactosyl-0-hydroxylysine; (Hyl[GlcGal]), $\alpha$-1-2-glucosyl-galactosyl-0-hydroxylysine; MRC, Medical Research Council; SCT, salmon calcitonin.
} 
collagen degradation is that its estimation provides no information concerning the source of collagen since its content varies little from one tissue collagen to another.

Hydroxylysine ( $\mathrm{Hyl}$ ) is another amino acid unique to collagens and proteins containing collagen-like sequences. Like $\mathrm{Hyp}, \mathrm{Hyl}$ is not reutilized for collagen biosynthesis and although it is considerably less abundant than Hyp, it is a potential marker for collagen metabolism. A variable proportion of $\mathrm{Hyl}$ residues in collagen are glycosylated as $\beta$-1-galactosyl0 -hydroxylysine ( $\mathrm{Hyl}[\mathrm{Gal}])$ and some of these residues may be glucosylated as $\alpha$-1-2-glucosyl-galactosyl-0hydroxylysine (Hyl[GlcGal]) $(5,6)$. The relative proportion and total content of glycosylated $\mathrm{Hyl}$ are different for different collagens. For example the ratio $\mathrm{Hyl}(\mathrm{GlcGal}) / \mathrm{Hyl}(\mathrm{Gal})$ is $0.47 \pm 0.09$ in human bone, but $2.06 \pm 0.47$ in human skin (7). Cunningham et al. (5) and Kakimoto and Akazawa (8) identified these Hyl glycosides in normal human urine and Segrest and Cunningham (9) suggested that since they were not metabolized to the same extent as Hyp, they could serve as more quantitative markers for collagen breakdown as well as provide information as to the source of the collagen metabolites.

In the present study we have measured the urinary excretion of $\mathrm{Hyp}, \mathrm{Hyl}$, and $\mathrm{Hyl}$ glycosides in normal subjects and patients with accelerated collagen breakdown, particularly in disorders of the skeleton, to determine relative contributions of different collagenous tissues to the urinary pool of collagen degradation products. At high rates of bone collagen breakdown the excretion of $\mathrm{Hyl}$ and $\mathrm{Hyl}$ glycosides reflects the major contribution of bone collagen, but at low rates of turnover, induced by agents which suppress bone resorption, the contribution of components other than bone and skin becomes evident.

\section{METHODS}

Sample collection. All 24-h urine samples were collected after the subjects had been on a low gelatin diet for at least $24 \mathrm{~h}$. In some instances only first morning postabsorptive urinary samples were obtained. Samples were stored under toluene at $2-5^{\circ} \mathrm{C}$ and when collections were completed they were filtered and kept at $-20^{\circ} \mathrm{C}$. Samples were freezedried either before or after storage at $-20^{\circ} \mathrm{C}$. 24-h urine samples were obtained from 21 untreated subjects with Paget's disease of bone. Five of these subjects were subsequently treated with the diphosphonate disodium etidronate (EHDP) (10) at doses of $1-20 \mathrm{mg} / \mathrm{kg}$ for up to 12 mo and urine samples were again collected at 3-6 mo intervals. Four subjects with Paget's disease were treated with 50-200 Medical Research Council (MRC) U per day of salmon calcitonin (11) for 16-32 mo; pre and post-treatment urinary samples were collected from these individuals at various intervals. Five pagetic and two normal control subjects were given single intravenous or subcutaneous injections of calcitonin and urines collected at 30-60 min inter- vals. 24-h urine samples were collected from four patients with burns covering an estimated $50-88 \%$ of body surface. Multiple urine samples from two subjects with hereditary hyperphosphatasia were supplied through the courtesy of Dr. Melvin Horwith (New York Hospital-Cornell Medical Center, New York).12-h specimens were collected before and during human calcitonin therapy in one of these. Samples of bone from pagetic and normal subjects were obtained at time of hip surgery for pagetic coxopathy or at necropsy. Fascia and skin were obtained at necropsy from two additional subjects who did not have obvious disease of collagenous tissues.

\section{Preparation of samples}

Bone. Fragments of normal and pagetic bone were cleaned and stripped of periosteum. Specimens were demineralized with three changes of $0.5 \mathrm{M}$ disodium EDTA in $0.1 \mathrm{M}$ Tris$\mathrm{HCl}, \mathrm{pH} 8.0,20 \mathrm{ml} / \mathrm{g}$ of tissue, over a period of 3 days, at $5^{\circ} \mathrm{C}$ with constant agitation by means of a magnetic stirrer (7). The samples were rinsed with distilled water and freeze-dried. No Hyl or Hyp was found on amino acid analysis of acid hydrolysates of the supernatant solutions.

Skin. Fat and hair were stripped by dissection and the skin placed in $2 \mathrm{M} \mathrm{NaBr}$ at $20^{\circ} \mathrm{C}$ for $12 \mathrm{~h}$, allowing the epidermis to be peeled away from the dermis $(12,13)$. The dermis was rinsed with distilled water and freezedried.

Fascia. Any muscle was stripped off by dissection and the fascia rinsed with distilled water and freeze-dried.

Analysis of total Hyl and Hyp. Samples of bone, skin, and fascia (approximately $8 \mathrm{mg}$ dry weight) and 1-5 ml equivalents of freeze-dried urine were hydrolyzed under nitrogen in sealed tubes in constant boiling $\mathrm{HCl}$ at $108^{\circ} \mathrm{C}$ for $20 \mathrm{~h}$. The samples were then dried in a desiccator containing solid $\mathrm{NaOH}$ under vacuum. Dried hydrolysates were quantitatively transferred with $0.1 \mathrm{~N} \mathrm{HCl}$ to $5-\mathrm{ml}$ volumetric flasks and brought to final volume. $500 \mu \mathrm{l}$ of solution was used for amino acid anlysis. Quantitative amino acid analyses (14) were performed with a modified model 117 Beckman-Spinco automatic amino acid analyzer (Beckman Instruments Inc., Spinco Div., Palo Alto, Calif.).

Base hydrolysis and $\mathrm{Hyl}$ glycoside determination. Dry tissues (15-20 mg) and appropriate amounts of urine (7) (according to concentration) were used. Specimens were hydrolyzed in $2 \mathrm{~N} \mathrm{KOH}$ in alkali-resistant boron-free hydrolysis tubes at $108^{\circ} \mathrm{C}$ for $20 \mathrm{~h}$. The solutions were neutralized to $\mathrm{pH} 7$ with $1 \mathrm{M} \mathrm{HClO}_{4}$. Samples were centrifuged at $1,000 \mathrm{rpm}$ at room temperature for $5 \mathrm{~min}$; the supernates were removed and freeze-dried. Samples were quantitatively transferred to a Bio Gel P-2 (200-400 mesh) gel filtration column $(100 \times 1.8 \mathrm{~cm})$ (Bio-Rad Laboratories, Richmond, Calif.) in a total of $2 \mathrm{ml}$ of $0.1 \mathrm{~N}$ acetic acid. 150 fractions (each $2.2 \mathrm{ml}$ ) were collected with an LKB fraction collector (LKB Instruments Inc., Rockville, Md.). Fractions numbered 51-75 (containing $\mathrm{Hyl}$ and its glycosides) were pooled and freeze-dried. These were then placed on the amino acid analyzer column.

Other methods. Creatinine was determined by the method of Folin (15). Determinations of Clq by radioimmunodiffusion were performed through the courtesy of Dr. Peter Schur at the Robert Breck Brigham Hospital.

\section{RESULTS}

The values for urinary excretion of $\mathrm{Hyl}$ and each of its glycosides by five normal adults before calcitonin 
TABLE I

Urinary Excretion of Collagen Metabolites in Normal Subjects

\begin{tabular}{|c|c|c|c|c|c|c|c|}
\hline & \multirow[b]{3}{*}{ Number } & \multicolumn{2}{|c|}{ Total } & \multirow[b]{2}{*}{ Hyl(GlcGal) } & \multirow[b]{2}{*}{ Hyl } & \multirow[b]{2}{*}{ Hyl(GlcGal) } & \multirow[b]{2}{*}{$\mathrm{Hyl}(\mathrm{Gal})$} \\
\hline & & Нyp & Hyl & & & & \\
\hline & & creatinine & Нyp & $\mathrm{Hyl}(\mathrm{Gal})$ & creatinine & creatinine & creatinine \\
\hline & & $\mu \mathrm{mol} / \mathrm{mg}$ & $\mathrm{mol} / \mathrm{mol}$ & $\mathrm{mol} / \mathrm{mol}$ & & $\mu \mathrm{mol} / \mathrm{mg}$ & \\
\hline $\begin{array}{c}\text { Adults* } \\
\text { mean } \\
\text { (range) }\end{array}$ & 5 & $\begin{array}{c}0.173 \\
(0.075-0.300)\end{array}$ & $\begin{array}{c}0.216 \\
(0.096-0.418)\end{array}$ & $\begin{array}{c}1.44 \\
(0.94-2.53)\end{array}$ & $\begin{array}{c}0.0073 \\
(0.0225-0.0343)\end{array}$ & $\begin{array}{c}0.0115 \\
(0.0087-0.0193)\end{array}$ & $\begin{array}{c}0.0082 \\
(0.0069-0.0093)\end{array}$ \\
\hline $\begin{array}{c}\text { Children } \downarrow \\
\text { mean } \\
\text { (range) }\end{array}$ & 8 & $\begin{array}{c}1.18 \\
(0.95-1.37)\end{array}$ & $\begin{array}{c}0.117 \\
(0.088-1.36)\end{array}$ & $\begin{array}{c}0.94 \\
(0.87-1.12)\end{array}$ & $\begin{array}{c}0.0361 \\
(0.0232-0.0701)\end{array}$ & $\begin{array}{c}0.0484 \\
(0.0416-0.0562)\end{array}$ & $\begin{array}{c}0.0517 \\
(0.0435-0.0593)\end{array}$ \\
\hline
\end{tabular}

* Present study.

$\ddagger$ Calculated from Pinnell et al. (12).

treatment are shown in Table I. The values for $\mathrm{Hyl}(\mathrm{Gal})$ are within the range of normal adult males (0.004-0.021 $\mu \mathrm{mol} / \mathrm{mg}$ creatinine) calculated from the data of Kakimoto and Akazawa (8). The levels of $\mathrm{Hyl}(\mathrm{GlcGal})$ are in the lower portion of the range calculated from the data of Kakimoto and Akazawa (8) although it is not known if the latter subjects were on gelatinfree diets. In their two patients on protein restriction the levels of $\mathrm{Hyl}(\mathrm{GlcGal})(0.010 \mu \mathrm{mol} / \mathrm{mg}$ creatinine in both) were similar to those shown in Table $I$. Values for normal children, ages 7-12, calculated from previously reported data (12) are also shown. The excretion of total $\mathrm{Hyl}$ is greater in children than in adults, as is the excretion of total Hyp, and the ratio of $\mathrm{Hyl}(\mathrm{GlcGal}) / \mathrm{Hyl}(\mathrm{Gal})$ is lower in children than in adults. Each of our patients with untreated bone disease excreted $\mathrm{Hyl}$ and $\mathrm{Hyl}$ glycosides at levels outside the ranges of those of the normal subjects. The levels in patients with bone disease were proportional to the total Hyp excretion when Hyp/creatinine was greater than $2.0 \mu \mathrm{mol} / \mathrm{mg}$. In the patients with Paget's disease these levels were also correlated with extent and activity of the disease (16). In untreated patients, there was little variation in the urinary excretion of $\mathrm{Hyp}, \mathrm{Hyl}$, and its glycosides when sampled at intervals during the day, and little variation $( \pm 10 \%$ of mean) in untreated patients from day to day when the values were normalized to creatinine excretion. Therefore, in some subjects only first morning postabsorptive urine samples were included for analysis. When normal subjects were treated with calcitonin and patients with Paget's disease treated with calcitonin or EHDP, the total excretion of $\mathrm{Hyl}$ and its glycosides decreased as did the excretion of Hyp. The fraction of total $\mathrm{Hyl}$ in the urine that was glycosylated was similar in all samples $(n=67)$ and averaged $0.754 \pm 0.078(\mathrm{SD})$, in agreement with the value of 0.78 calculated from the data of Kakimoto and Akazawa (8).

In two urine samples with high total Hyp and $\mathrm{Hyl}, \mathrm{Hyl}$ and glycosides were determined before and after alkaline hydrolysis. Levels of free $\mathrm{Hyl}(\mathrm{GlcGal})$ were 94 and $73 \%$ of the total $\mathrm{Hyl}(\mathrm{GlcGal})$, of $\mathrm{Hyl}$ (Gal) 95 and $89 \%$ of total $\mathrm{Hyl}(\mathrm{Gal})$ and of $\mathrm{Hyl} 47$ and $32 \%$ of total Hyl. In samples with low total Hyp and $\mathrm{Hyl}$, determination of free $\mathrm{Hyl}$ and glycosides would necessitate placing large volumes of unhydrolyzed urine on the gel filtration and analyzer columns. To avoid clogging the columns we continued to analyze samples after alkaline hydrolysis.

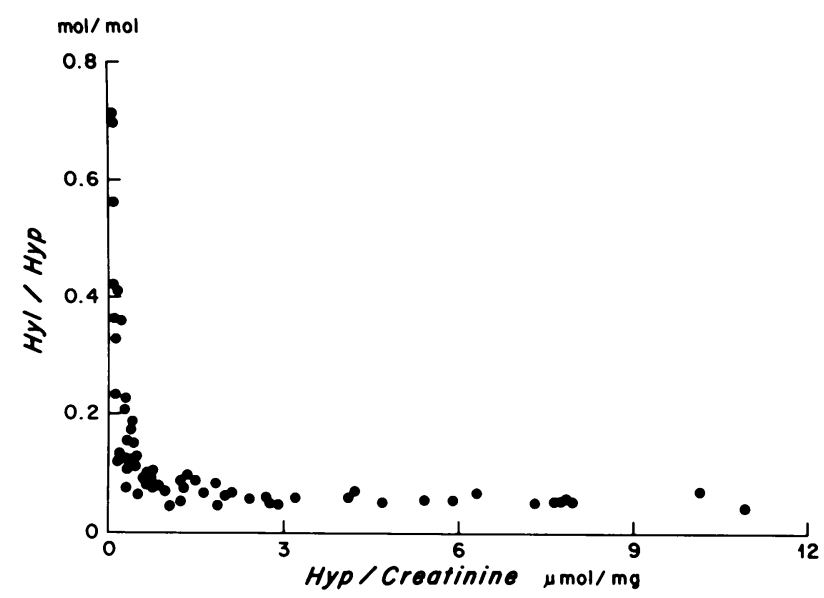

Figure 1 The molar ratio of urinary $\mathrm{Hyl} / \mathrm{Hyp}$ as a function of urinary total Hyp normalized to creatinine excretion ( $\mathrm{Hyp} / \mathrm{creatinine})$ in patients with Paget's disease (treated and untreated) and in normal subjects (with and without calcitonin treatment). Values include data from acute as well as chronic administration of calcitonin. Not included are values for two children with hyperphosphatasia with control excretion of $\mathrm{Hyp} /$ creatinine of 27.1 and $19.0 \mu \mathrm{mol} /$ $\mathrm{mg}$ and $\mathrm{Hyl} / \mathrm{Hyp}$ ratios of 0.034 and 0.047 , respectively. 


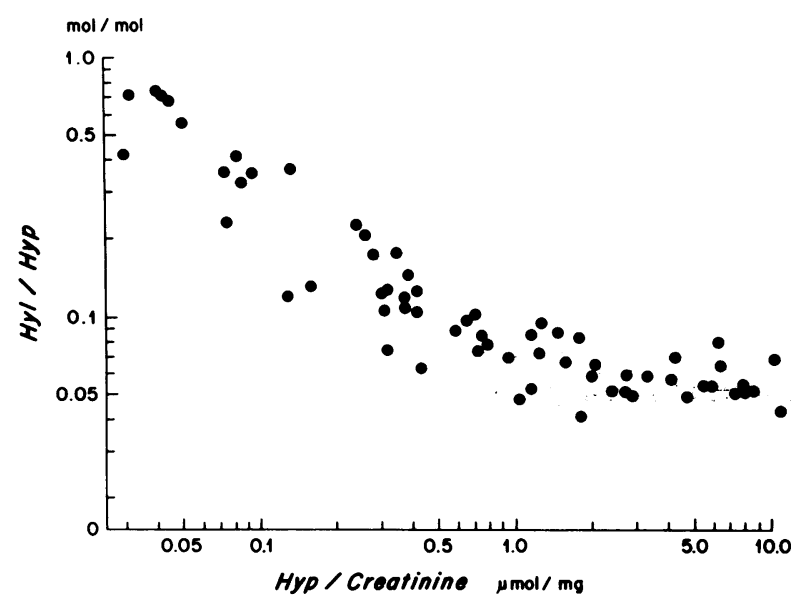

Figure 2 Data from Fig. 1 plotted on a log-log scale. At lowest values of $\mathrm{Hyp} /$ creatinine, ratios of $\mathrm{Hyl} / \mathrm{Hyp}$ can be extrapolated to approximately $0.5-0.7$.

Relationship of urinary Hyl to Hyp. In Fig. 1 the molar ratio of urinary $\mathrm{Hyl} / \mathrm{Hyp}$ in control and untreated and treated patients with bone disease is plotted as a function of total Hyp excretion normalized to urinary creatinine. The ratio $\mathrm{Hyl} / \mathrm{Hyp}$ fell with increasing levels of Hyp excretion. Patients with Paget's disease or hyperphosphatasia and very high urinary $\mathrm{Hyp}$, i.e. $>2.0 \mu \mathrm{mol} / \mathrm{mg}$ creatinine, had a mean molar ratio of urinary $\mathrm{Hyl} / \mathrm{Hyp}$ of $0.052 \pm 0.002$ (SEM). This value remained constant with increasing levels

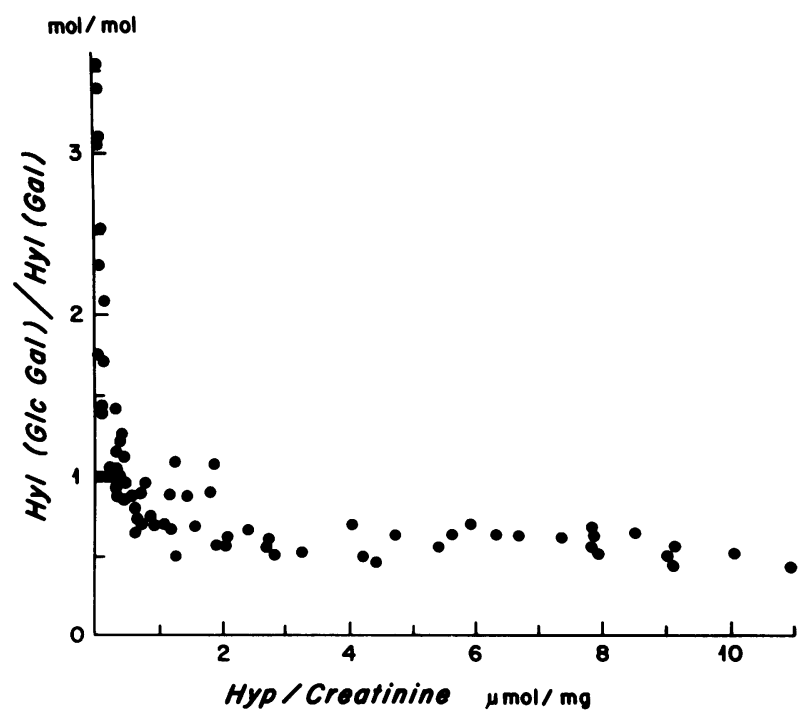

FIGURE 3 The molar ratio of urinary $\mathrm{Hyl}(\mathrm{GlcGal}) / \mathrm{Hyl}(\mathrm{Gal})$ as a function of urinary total $\mathrm{Hyp}$ normalized to creatinine excretion ( $\mathrm{Hyp} / \mathrm{creatinine})$ in same patient population described in Fig. 1. Not included are values for the two children with hyperphosphatasia with control excretion of Hyp/creatinine of 27.1 and $19.0 \mu \mathrm{mol} / \mathrm{mg}$ and $\mathrm{Hyl}(\mathrm{Glc}-$ $\mathrm{Gal}) / \mathrm{Hyl}(\mathrm{Gal})$ ratios of 0.67 and 0.69 , respectively. of Hyp over a wide range (to $28.0 \mu \mathrm{mol} \mathrm{Hyp} / \mathrm{mg}$ creatinine). In patients with milder disease, both treated and untreated, the urinary ratio of $\mathrm{Hyl} / \mathrm{Hyp}$ rose with decreasing excretion of Hyp. The highest values were reached in normal subjects given calcitonin acutely.

In Fig. 2 the data shown in Fig. 1 are replotted on a log-log scale to illustrate better the two components of the curve. A plateau is reached at levels of Hyp excretion greater than approximately $2 \mu \mathrm{mol} / \mathrm{mg}$ creatinine. At very low values of $\mathrm{Hyp}$ the ratio is extrapolated to approximately 0.5-0.7.

Relationship of urinary $\mathrm{Hyl}(\mathrm{GlcGal})$ and $\mathrm{Hyl}(\mathrm{Gal})$ to Hyp. In Fig. 3 the molar ratio of urinary Hyl(GlcGal)/Hyl(Gal) is plotted as a function of total urinary Hyp in normal subjects and untreated and treated patients with bone disease. The ratio fell with increasing levels of Hyp excretion, with a mean of $0.601 \pm 0.017(\mathrm{SEM})$ at levels of urinary $\mathrm{Hyp} /$ creatinine $>2.0 \mu \mathrm{mol} / \mathrm{mg}$. The decrease in the ratio $\mathrm{Hyl}(\mathrm{GlcGal}) / \mathrm{Hyl}(\mathrm{Gal})$ is accounted for by a relatively larger contribution of $\mathrm{Hyl}(\mathrm{Gal})$ at the high excretions of Hyp. This is illustrated in Fig. 4 where the excretion of $\mathrm{Hyl}$ glycosides is plotted as a function of total $\mathrm{Hyl}$ excretion in treated and untreated patients with Paget's disease. The slope for the $\mathrm{Hyl}(\mathrm{Gal})$ data is steeper; therefore, at increasing concentrations of total $\mathrm{Hyl}$ in patients with Paget's disease,

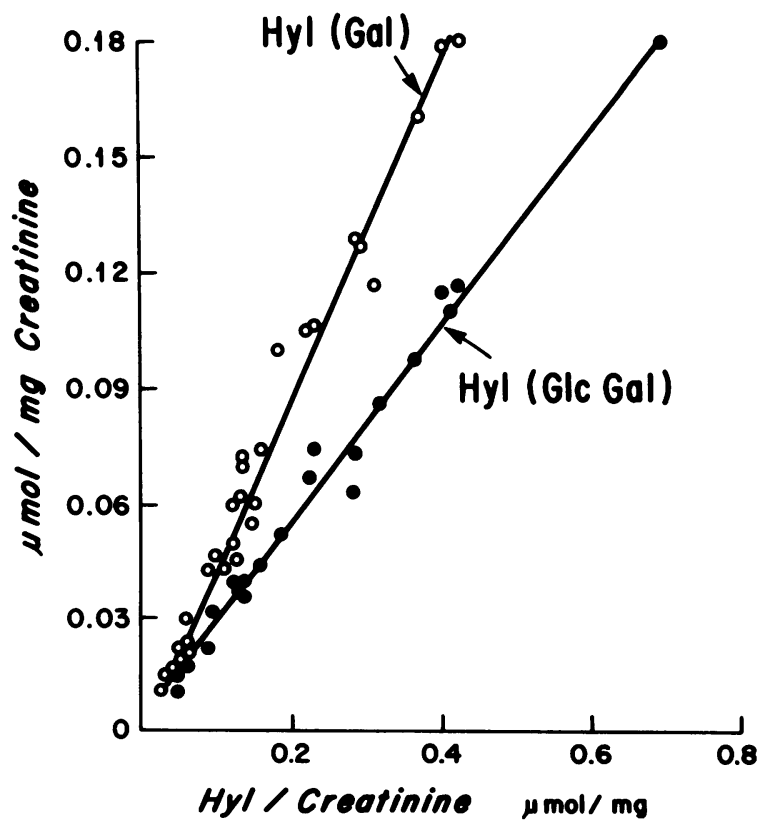

FIGURE 4 Urinary excretion of $\mathrm{Hyl}(\mathrm{Gal})$ (open circles) and $\mathrm{Hyl}(\mathrm{GlcGal})$ (closed circles) normalized to creatinine as a function of urinary excretion of total $\mathrm{Hyl}$ normalized to creatinine in patients with Paget's disease, treated and untreated. 
TABLE II

Effect of Chronic Therapy with Salmon Calcitonin (SCT) on Urinary Collagen Metabolites in Patients with Paget's Disease of Bone

\begin{tabular}{|c|c|c|c|c|}
\hline \multirow[b]{2}{*}{ Patient } & \multirow[b]{2}{*}{ Treatment } & \multirow{2}{*}{$\frac{\mathrm{Hyp}}{\text { creatinine }}$} & \multirow{2}{*}{$\frac{\mathrm{Hyl}}{\mathrm{Hyp}}$} & \multirow{2}{*}{$\frac{\mathrm{Hyl}(\mathrm{GlcGal})}{\mathrm{Hyl}(\mathrm{Gal})}$} \\
\hline & & & & \\
\hline \multirow{3}{*}{1} & & $\mu \mathrm{mol} / \mathrm{mg}$ & $\mathrm{mol} / \mathrm{mol}$ & $\mathrm{mol} / \mathrm{mol}$ \\
\hline & None & 2.88 & 0.048 & 0.51 \\
\hline & $\begin{array}{l}\text { SCT } 100 \mathrm{MRC} \text { U/day } \\
\times 15 \mathrm{mo}\end{array}$ & 0.95 & 0.069 & 0.70 \\
\hline \multirow[t]{2}{*}{2} & None & 3.24 & 0.057 & 0.53 \\
\hline & $\begin{array}{l}\text { SCT } 50 \mathrm{MRC} \mathrm{U} / \text { day } \\
\quad \times 24 \mathrm{mo}\end{array}$ & 0.62 & 0.078 & 0.65 \\
\hline \multirow[t]{2}{*}{3} & None & 1.05 & 0.047 & 0.70 \\
\hline & $\begin{array}{l}\text { SCT } 50 \mathrm{MRC} \mathrm{U/day} \\
\times 8 \mathrm{mo}\end{array}$ & 0.32 & 0.073 & 1.43 \\
\hline
\end{tabular}

monosaccharide $\mathrm{Hyl}$ contributes an increasing percentage of the total. In normal subjects and paients with total urinary $\mathrm{Hyp}<2.0 \mu \mathrm{mol} / \mathrm{mg}$ creatinine, the ratio of urinary $\mathrm{Hyl}(\mathrm{GlcGal}) / \mathrm{Hyl}(\mathrm{Gal})$ rose with decreasing excretion of Hyp. Highest values, approaching 3.5, were reached in normal subjects given calcitonin acutely.

Effects of calcitonin therapy. Measurements of urinary excretion of $\mathrm{Hyl}$ and its glycosides were obtained in three patients with Paget's disease who were treated chronically with salmon calcitonin for 16-32 mo at doses of 50-100 MRC units per day. As long as total $\mathrm{Hyp}$ was $>2 \mu \mathrm{mol} / \mathrm{mg}$ creatinine the ratios of $\mathrm{Hyl} / \mathrm{Hyp}$ and $\mathrm{Hyl}(\mathrm{GlcGal}) / \mathrm{Hyl}(\mathrm{Gal})$ remained constant over a wide range of Hyp excretion $(2->10 \mu \mathrm{mol} / \mathrm{mg}$ creatinine); changes in ratios were observed only when the post-therapy Hyp was decreased to $<2.0$ $\mu \mathrm{mol} / \mathrm{mg}$ creatinine. Pre and post-treatment values are shown in Table II. The ratio of $\mathrm{Hyl} / \mathrm{Hyp}$ rose by an average of 0.023 and that of $\mathrm{Hyl}(\mathrm{GlcGal}) / \mathrm{Hyl}(\mathrm{Gal})$ by an average of 0.023 and that of $\mathrm{Hyl}(\mathrm{GlcGal}) /$ $\mathrm{Hyl}(\mathrm{Gal})$ by an average of 0.347 as a result of treatment.

Five pagetic patients were given salmon calcitonin intravenously $(8-20 \mu \mathrm{g})$ and acute changes measured. All exhibited decreases in urinary Hyp (average 2.97 $\mu \mathrm{mol} / \mathrm{mg}$ creatinine) accompanied by increases in the ratio of $\mathrm{Hyl}(\mathrm{GlcGal}) / \mathrm{Hyl}(\mathrm{Gal})$ (average 0.25$)$ and that of $\mathrm{Hyl} / \mathrm{Hyp}$ (average 0.057). Within $2 \mathrm{~h}$ in one patient, urinary Hyp had fallen from 0.81 to $0.36 \mu \mathrm{mol} / \mathrm{mg}$ creatinine, while the $\mathrm{Hyl} / \mathrm{Hyp}$ ratio rose from 0.081 to 1.30 and the $\mathrm{Hyl}(\mathrm{GlcGal}) / \mathrm{Hyl}(\mathrm{Gal})$ ratio rose from 0.66 to 0.94. A typical response is shown in Fig. 5 .

In Table III are shown the values for urinary Hyp, $\mathrm{Hyl}$, and Hyl glycosides in samples from a patient with hereditary hyperphosphatasia. The ratios of $\mathrm{Hyl} /$

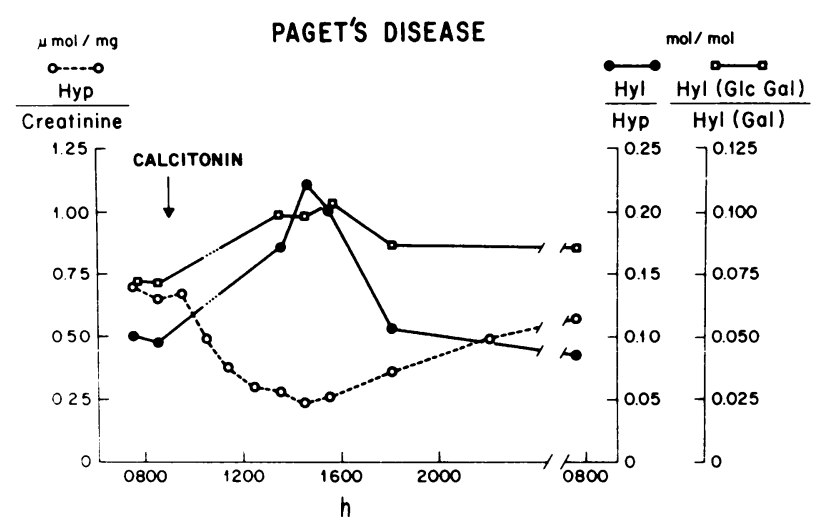

FIGURE 5 Acute response of urinary excretion of total $\mathrm{Hyp} /$ creatinine and molar ratios of $\mathrm{Hyl} / \mathrm{Hyp}$ and $\mathrm{Hyl}(\mathrm{GlcGal}) /$ $\mathrm{Hyl}(\mathrm{Gal})$ to administration of $10 \mu \mathrm{g}$ of salmon calcitonin intravenously to a patient with Paget's disease.

Hyp and $\mathrm{Hyl}(\mathrm{GlcGal}) / \mathrm{Hyl}(\mathrm{Gal})$ in this patient represent the highest values for total Hyp excretion shown in Figs. 1-3 and indicate the constancy of these ratios in bone disease even at extreme values of Hyp excretion. After treatment with human calcitonin ( $1 \mathrm{mg} /$ day) Hyp excretion fell sharply in the first 12 -h samples collected each day. Values returned to pretreatment levels during the second $12 \mathrm{~h}$. The Hyl-derived ratios were not significantly altered.

Two normal subjects were given calcitonin intravenously. Their post-treatment ratios of $\mathrm{Hyl} / \mathrm{Hyp}$ and $\mathrm{Hyl}(\mathrm{GlcGal}) / \mathrm{Hyl}(\mathrm{Gal})$ rose to 0.71 and 0.72 and 2.29 and 3.54 , respectively, at the nadir of Hyp excretion.

Results of therapy with EHDP. In five patients with Paget's disease treated with EHDP, post-therapy ratios of $\mathrm{Hyl} / \mathrm{Hyp}$ and $\mathrm{Hyl}(\mathrm{GlcGal}) / \mathrm{Hyl}(\mathrm{Gal})$ rose as

TABLE III

Effect of Treatment with Human Calcitonin on Urinary Collagen Metabolites in a Patient with Hyperphosphatasia

\begin{tabular}{|c|c|c|c|c|c|}
\hline \multirow[b]{2}{*}{ Day } & \multirow[b]{2}{*}{ Time } & \multirow[b]{2}{*}{ Treatment } & \multirow{2}{*}{$\frac{\text { Hyp }}{\text { Creatinine }}$} & \multirow{2}{*}{$\begin{array}{l}\text { Hyl } \\
\text { Hyp }\end{array}$} & \multirow{2}{*}{$\frac{\begin{array}{c}\text { Hyl- } \\
(\text { GlcGal) }\end{array}}{\text { Hyl(Gal) }}$} \\
\hline & & & & & \\
\hline \multirow[t]{2}{*}{1} & $0830-2030 \mathrm{~h}$ & None & 27.1 & 0.034 & 0.67 \\
\hline & $2030-0830 \mathrm{~h}$ & None & 29.2 & 0.033 & 0.73 \\
\hline \multirow[t]{2}{*}{2} & $0830-2030 \mathrm{~h}$ & None & 29.2 & 0.036 & 0.73 \\
\hline & $2030-0830 \mathrm{~h}$ & None & 26.5 & 0.033 & 0.66 \\
\hline \multirow[t]{2}{*}{3} & $0900-2100 \mathrm{~h}$ & SCT $200 \mathrm{U}$ & 13.3 & 0.038 & 0.81 \\
\hline & $2100-0900 \mathrm{~h}$ & 0 & 25.2 & 0.038 & 0.73 \\
\hline \multirow[t]{2}{*}{4} & $0900-2100 \mathrm{~h}$ & SCT $200 \mathrm{U}$ & 15.2 & 0.046 & 0.79 \\
\hline & $2100-0900 \mathrm{~h}$ & 0 & 24.2 & 0.039 & 0.65 \\
\hline
\end{tabular}




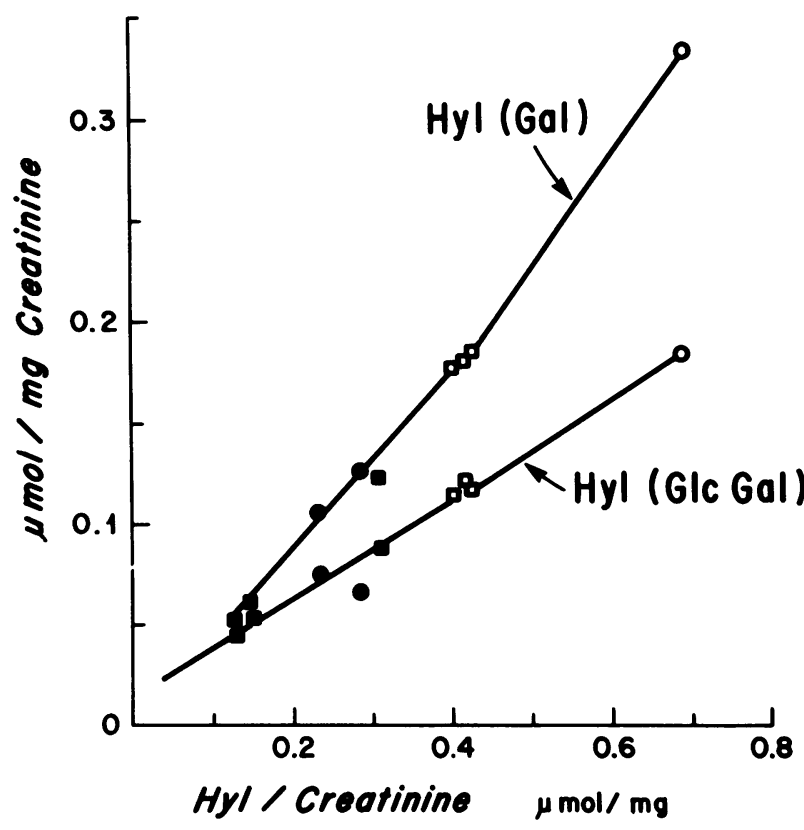

FIGURE 6 Urinary excretion of $\mathrm{Hyl}(\mathrm{Gal})$ and $\mathrm{Hyl}(\mathrm{GlcGal})$ as a function of urinary excretion of total $\mathrm{Hyl}$, with all values normalized to creatinine. The open circles are the pretreatment values for a patient with Paget's disease treated with 100-200 MRC units daily of salmon calcitonin over a period of $2.5 \mathrm{yr}$. The closed circles are values obtained after 2.0 and $2.5 \mathrm{yr}$ of therapy. The open squares are the pretreatment values for another patient with Paget's disease. Closed squares are values obtained while on daily therapy with EHDP showing progressive decline after 9 mo of $5 \mathrm{mg} / \mathrm{kg}$, an additional $3 \mathrm{mo}$ of $20 \mathrm{mg} / \mathrm{kg}$, and an additional $6 \mathrm{mo}$ of $20 \mathrm{mg} / \mathrm{kg}$.

total Hyp excretion fell. These values are included in the data shown in Figs. 1-4.

In Fig. 6 the effect of therapy with EHDP is compared to that with salmon calcitonin on the urinary excretion of Hyl glycosides by two paients with Paget's disease. In both treatments there was a more profound decline in $\mathrm{Hyl}(\mathrm{Gal})$ than in $\mathrm{Hyl}(\mathrm{GlcGal})$. However the values for both therapies fell along similar curves.

Analysis of tissues from patients with Paget's disease. Since the patients with untreated Paget's disease had ratios of $\mathrm{Hyl} / \mathrm{Hyp}$ and $\mathrm{Hyl}(\mathrm{GlcGal}) / \mathrm{Hyl}(\mathrm{Gal})$ in urine different from those in normal subjects, and since it is presumed that the collagen degradation products in pagetic patients are derived predominantly from bone, information on the composition of pagetic bone collagen is essential for interpretation of such data. Results of amino acid analysis and determination of $\mathrm{Hyl}$ and its glycosides in bone from five patients with Paget's disease are presented in Table IV. There was no significant difference in the amino acid composition of pagetic versus normal bone. The $\mathrm{Hyl} / \mathrm{Hyp}$ ratio of pagetic bone was $0.050 \pm 0.010$ (range $0.35-0.067$ ), not significantly different from the value for normal bone of $0.042 \pm 0.009$ (7). The ratio of $\mathrm{Hyl}(\mathrm{GlcGal}) / \mathrm{Hyl}(\mathrm{Gal})$ was $0.480 \pm 0.150$, not significantly different from the normal value of $0.474 \pm 0.088$. A single sample from a pagetic vertebral body did have a ratio of 0.743 , significantly greater than normal. There have been reports contending that skin of pagetic subjects is abnormal, showing features of pseudoxanthoma elasticum (17). Analysis of samples of dermis from two of our patients revealed a normal amino acid composition including a $\mathrm{Hyl} / \mathrm{Hyp}$ ratio of $\mathbf{0 . 0 4 9}$ and $\mathbf{0 . 0 6 4}$, not significantly different from the normal dermal value of $0.048 \pm 0.005$ (12) whereas the ratio of $\mathrm{Hyl}(\mathrm{GlcGal}) / \mathrm{Hyl}(\mathrm{Gal})$ in the single specimen analyzed was 1.60, also within the range of normal dermis. Thus the low ratio of $\mathrm{Hyl} / \mathrm{Hyp}$ in association with the low ratio of $\mathrm{Hyl} / \mathrm{GlcGal} / \mathrm{Hyl}(\mathrm{Gal})$ found in the urine of patients with extensive Paget's disease is compatible with bone collagen as the major source of degradation.

Analysis of urine from patients with thermal burns. Since the ratio of $\mathrm{Hyl} / \mathrm{Hyp}$ in normal dermis, 0.048 \pm 0.005 , is similar to that of bone but the ratio of $\mathrm{Hyl}(\mathrm{GlcGal}) / \mathrm{Hyl}(\mathrm{Gal})$ very much higher than bone, it would be expected that patients with thermal burns would show a pattern of urinary degradation products different from patients with Paget's disease relative to total Hyp excretion. In three adults with extensive burns the results, shown in Table $V$, were as predicted. Hyl/Hyp ratios were somewhat higher than expected and could be accounted for by a contribution not only from dermis but from fascia which has a higher $\mathrm{Hyl} / \mathrm{Hyp}$ ratio than skin (12). Indeed, normal deep fascia obtained at necropsy from two additional normal subjects showed the ratio of $\mathrm{Hyl} / \mathrm{Hyp}$ to be 0.074 and 0.068 and that of $\mathrm{Hyl}(\mathrm{GlcGal}) / \mathrm{Hyl}(\mathrm{Gal})$ to be 1.35 and 1.89 .

\section{DISCUSSION}

Since the Hyl glycosides were first isolated from urine by Cunningham et al. in 1967 (5) they have been found in both invertebrate (18) and vertebrate collagens $(6$, 19). The urinary Hyl glycosides are metabolic products of endogenous collagen (19), and their excretion roughly parallels excretion of $\mathrm{Hyp}$ in normal and diseased subjects.

There is previous evidence that measurements of urinary $\mathrm{Hyl}$ glycosides provide more accurate reflections of collagen degradation than measurements of urinary Hyp $(9,20)$. Segrest and Cunningham (9) calculated collagen turnover equivalents from urinary Hyl glycoside levels to be two to four times larger than those calculated from levels of urinary Hyp. Assuming that these estimations are accurate, $\mathrm{Hyl}$ glucoside excretion would account for $50-100 \%$ of degraded collagen. An explanation could be that the gly- 
TABLE IV

Chemical Composition of Pagetic Bone

\begin{tabular}{|c|c|c|c|c|c|c|}
\hline \multirow[b]{4}{*}{ Bone } & & \multicolumn{3}{|c|}{ Pagetic Bone } & \multirow[b]{2}{*}{5} & Control \\
\hline & 1 & 2 & 3 & 4 & & \multirow[b]{3}{*}{ Vertebrae } \\
\hline & Femur & Vertebra & Sacrum & Rib & Ilium & \\
\hline & \multicolumn{5}{|c|}{ Residues/1,000 residues } & \\
\hline 4-Hydroxyproline & 102 & 113 & 109 & 100 & 108 & $100.5^{*} \pm 5.9$ \\
\hline Aspartic Acid & 52 & 51 & 48 & 52 & 53 & $48.5 \pm 0.9$ \\
\hline Threonine & 21 & 21 & 19 & 21 & 21 & $18.0 \pm 0.9$ \\
\hline Serine & 37 & 38 & 36 & 39 & 38 & $36.2 \pm 0.8$ \\
\hline Glutamic Acid & 85 & 84 & 80 & 86 & 85 & $80.7 \pm 1.7$ \\
\hline Proline & 122 & 129 & 124 & 128 & 125 & $120.7 \pm 2.8$ \\
\hline Glycine & 290 & 277 & 307 & 281 & 282 & $311.0 \pm 3.8$ \\
\hline Alanine & 104 & 109 & 110 & 111 & 110 & $111.2 \pm 1.8$ \\
\hline $1 / 2$ Cystine & 1.4 & 0.6 & 0 & 0.5 & 0.9 & $0.3 \pm 0.1$ \\
\hline Valine & 26 & 25 & 23 & 20 & 26 & $24.2 \pm 1.7$ \\
\hline Methionine & 6.2 & 7.3 & 4.0 & 11.4 & 7.7 & $5.6 \pm 0.6$ \\
\hline Isoleucine & 11 & 11 & 10 & 11 & 12 & $10.2 \pm 0.8$ \\
\hline Leucine & 28 & 27 & 26 & 24 & 28 & $25.9 \pm 1.0$ \\
\hline Tyrosine & 6 & 4.8 & 2.5 & 5.5 & 5.3 & $4.0 \pm 0.2$ \\
\hline Phenylalanine & 15 & 15 & 13 & 18 & 16 & $13.6 \pm 1.0$ \\
\hline Hydroxylysine & 5.4 & 5.0 & 3.8 & 6.7 & 4.2 & $4.2 \pm 0.7$ \\
\hline Lysine & 28 & 24 & 28 & 28 & 20 & $29.0 \pm 2.8$ \\
\hline Histidine & 6.4 & 2.0 & 4.2 & 1.5 & 1.8 & $5.6 \pm 0.3$ \\
\hline Arginine & 52 & 55 & 51 & 55 & 56 & $48.5 \pm 2.4$ \\
\hline Total hydroxylysine & & & & & & \\
\hline Glycosides, \% & 27 & 33 & 33 & 27 & 56 & $30 \ddagger$ \\
\hline Hyl(GlcGal)/Hyl(Gal) & 0.422 & 0.743 & 0.396 & 0.464 & 0.390 & $0.474 \ddagger \pm 0.088$ \\
\hline Hyl/Hyp & 0.053 & 0.044 & 0.035 & 0.067 & 0.039 & $0.042 * \pm 0.009$ \\
\hline
\end{tabular}

* Mean \pm SD from Pinnell et al. (12).

$\downarrow$ Pinnell et al. (7).

cosides are protected from enzymatic degradation, as are prolylhydroxyprolyl peptides (4), or, alternatively, that the specific enzymes involved in degradation are absent. Hiles and Henderson (21) found hydroxylysine kinase to be present in the liver and/or kidney of rats, mice, chickens, cow, rabbits, and two species of primates but undetectable in human liver or kidney. Measurable activity of phosphohydroxylysine phosphorylase, another enzyme which may participate in Hyl degradation, was observed in human tissues (22).

Our data support the thesis that $\mathrm{Hyl}$ glycosides are only partially degraded and could provide a better index of collagen metabolism than urinary Hyp by indicating the source of the degraded collagen. The fraction of $\mathrm{Hyl}$ that is glycosylated is approximately 0.3 in bone and skin, the putative major sources of collagen degradation. However, the urinary fraction of glycosylated $\mathrm{Hyl} /$ total $\mathrm{Hyl}$ is greater than 0.7. Since there is no other known source of $\mathrm{Hyl}$ glycosides other than in collagens or in collagen-like sequences, the major change in this fraction could be accounted for by a decrease in the free $\mathrm{Hyl}$ denominator.
Patients with severe resorptive bone disease such as Paget's disease, and urinary $\mathrm{Hyp}>2.0 \mu \mathrm{mol} / \mathrm{mg}$ creatinine had a urinary $\mathrm{Hyl}(\mathrm{GlcGal}) / \mathrm{Hyl}(\mathrm{Gal})$ ratio of

TABLE V

Urinary Collagen Metabolites in Patients with Thermal Burns

\begin{tabular}{|c|c|c|c|c|c|}
\hline \multirow{2}{*}{$\begin{array}{c}\text { Patient } \\
\text { (age-sex) }\end{array}$} & \multirow{2}{*}{$\begin{array}{l}\text { Time of } \\
\text { collection } \\
\text { after burn }\end{array}$} & \multirow{2}{*}{$\begin{array}{c}\text { Estimated } \\
\text { extent } \\
\text { of burn }\end{array}$} & \multirow{2}{*}{$\frac{\text { Hyp }}{\text { creatinine }}$} & \multirow{2}{*}{$\begin{array}{l}\text { Hyl } \\
\text { Hyp }\end{array}$} & \multirow{2}{*}{$\frac{\mathrm{Hyl}(\mathrm{GlcGal})}{\mathrm{Hyl}(\mathrm{Gal})}$} \\
\hline & & & & & \\
\hline & days & $\%$ & $\mu m o l / m g$ & $\mathrm{~mol} / \mathrm{mol}$ & $\mathrm{mol} / \mathrm{mol}$ \\
\hline 1 & 54 & 70 & 3.42 & 0.083 & 0.64 \\
\hline$(60-M)$ & 85 & & 3.01 & 0.108 & 0.71 \\
\hline $\begin{array}{c}2 \\
(29-F)\end{array}$ & 16 & 50 & 1.96 & 0.185 & 0.60 \\
\hline $\begin{array}{c}3 \\
(33-F)\end{array}$ & 2 & 88 & 1.48 & 0.087 & 0.71 \\
\hline $\begin{array}{c}4 \\
(17-M)\end{array}$ & 18 & 60 & 4.80 & 0.064 & 0.68 \\
\hline
\end{tabular}

Urinary Hydroxylysine Excretion 


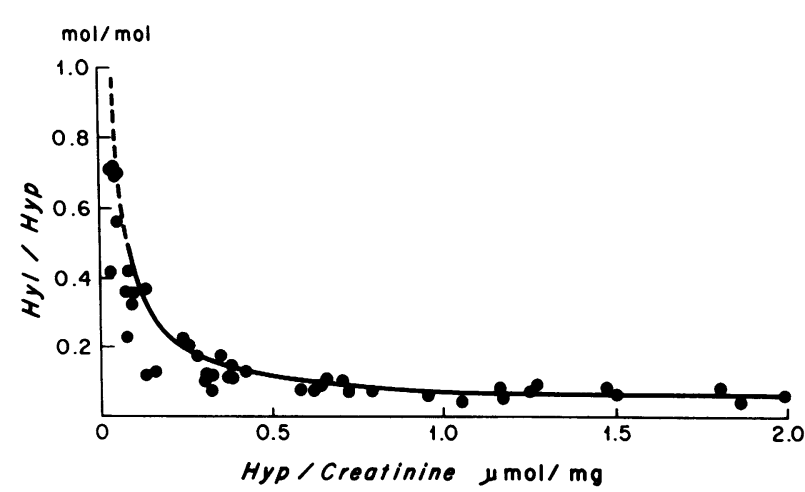

FIGURE 7 The molar ratio of urinary Hyl/Hyp as a function of urinary total Hyp normalized to creatinine. Curve is calculated assuming degradation products only from $\mathrm{Clq}$ and bone, as described in the text. Solid circles are data from subjects described in Figs. 1-3 but including only those with total urinary Hyp/creatinine $<2.0 \mu \mathrm{mol} / \mathrm{mg}$.

0.601 , similar to the value for bone and lower than that for skin. Thus the constant value reached at high excretions of Hyp approximates the normal value for bone, diluting out other influences. Since the ratios for urine and bone are similar, it is unlikely that the glycosides are metabolized to a significant degree. The composition of pagetic bone is similar to that of normal bone and therefore the ratio of urinary glycosides in Paget's disease is compatible with turnover of pagetic bone. In the paient with hyperphosphatasia calcitonin decreased urinary Hyp excretion during the first $12 \mathrm{~h}$ after injection but during the subsequent $12 \mathrm{~h}$ values returned to base line. However, the $\mathrm{Hyp} /$ creatinine ratio even on therapy remained extremely high, beyond the range of any of the untreated pagetic subjects. Thus, no significant rise in the ratios in $\mathrm{Hyl} / \mathrm{Hyp}$ or $\mathrm{Hyl}(\mathrm{GlcGal}) / \mathrm{Hyl}(\mathrm{Gal})$ was observed.

In patients with mild Paget's disease, both treated and untreated, urinary ratios of $\mathrm{Hyl} / \mathrm{Hyp}$ and $\mathrm{Hyl}(\mathrm{Glc}-$ $\mathrm{Gal} / \mathrm{Hyl}(\mathrm{Gal})$ rose with decreasing excretion of $\mathrm{Hyp}$. The highest values were found in normal subjects given calcitonin acutely. In the latter group, the $\mathrm{Hyl} /$ Hyp ratio approached 0.75 , greater than ten times values for skin or bone, and the $\mathrm{Hyl}(\mathrm{GlcGal}) / \mathrm{Hyl}(\mathrm{Gal})$ ratio approached 3.5, also much higher than that for skin or bone. Therefore, in normal subjects whose bone resorption is decreased by calcitonin, a different pattern of collagen metabolites is revealed. Potential sources for these metabolites could include cartilage (23) and basement membrane (24) collagens which have relatively high contents of $\mathrm{Hyl}$ and its glycosides, present mostly as $\mathrm{Hyl}(\mathrm{GlcGal})$. It is unlikely, however, that these collagens turn over at any significant rate.

A more likely candidate is Clq, a subcomponent of complement. It has a mol wt of 410,000 daltons and is probably composed of six noncovalently linked subunits, each of approximately $65,000 \mathrm{~mol}$ wt (25-27).
Each of these subunits contains three covalently linked polypeptide chains which differ in amino acid sequence. Included in the sequences are regions which contain the collagen-type repeat (Gly-X-Y), Hyp, and $\mathrm{Hyl}$, as well as $\mathrm{Hyl}(\mathrm{GlcGal})(27,28)$. The $\mathrm{Hyl} / \mathrm{Hyp}$ ratio reported is usually greater than 0.5 and most of the $\mathrm{Hyl}$ glycosides are in the disaccharide form. Kohler and Müller-Eberhard studied the metabolism of $\mathrm{Clq}$ in normals and in various pathologic states (29). With their data, we have calculated that Clq could account for as much as $0.08 \mu \mathrm{mol}$ of $\mathrm{Hyp} / \mathrm{mg}$ creatinine in normals and $0.68 \mu \mathrm{mol}$ in their patient with IgE myeloma.

An attempt was made to obtain data in individuals who might be expected to have high Clq turnover (patients with high serum globulins or febrile illness). None of these patients had ratios of $\mathrm{Hyl}(\mathrm{GlcGal}) /$ $\mathrm{Hyl}(\mathrm{Gal})$ or $\mathrm{Hyl} / \mathrm{Hyp}$ that deviated significantly from those plotted in Figs. 1 and 3 , or elevated $\mathrm{Clq}_{\mathrm{q}}$ values, although turnover of $\mathrm{Clq}$ was not measured. None of the patients studied by Kohler and MüllerEberhard (29) had elevated serum Clq concentrations, although all had increased turnover. Based on our previous calculation that Clq could account for approximately $0.08 \mu \mathrm{mol} \mathrm{Hyp} / \mathrm{mg}$ creatinine in normals, and assuming a ratio of $\mathrm{Hyl} / \mathrm{Hyp}$ in $\mathrm{Clq}$ of approximately $0.5(25)$ and that bone is the only other source of collagen breakdown products, a theoretical curve for $\mathrm{Hyl} / \mathrm{Hyp}$ as a function of total Hyp could be calculated (Fig. 7). The observed data showed a reasonable fit with the calculated curve. Thus, it is possible but not proven that metabolism of Clq is responsible for the high values for $\mathrm{Hyl}(\mathrm{GlcGal}) / \mathrm{Hyl}(\mathrm{Gal})$ seen in our patients when bone collagen degradation is suppressed.

An additional possible explanation for the increase in the ratio of $\mathrm{Hyl}(\mathrm{GlcGal}) / \mathrm{Hyl}(\mathrm{Gal})$ is that the glycosides may be derived from the higher molecular weight portion of the urinary collagen metabolites (retentate) which reflect new collagen synthesis (30). Although the ratio we have determined in preliminary studies, 1.7 , is higher than that of bone collagen, the presence of this fraction alone cannot account for changes in the composition of $\mathrm{Hyl}$ glycosides during treatment of Paget's disease, since the rise in that urinary fraction accompanying therapy was of insufficient magnitude to affect the glycoside ratio.

The results of therapy of Paget's disease with either calcitonin or EHDP are consistent with a specific decrease in bone collagen resorption rather than collagen resorption in general. The relatively high urinary ratio of $\mathrm{Hyl} / \mathrm{Hyp}$ in patients with extensive burns probably reflects involvement of collagenous structures deep to the dermis such as fascia, which have higher Hyl/Hyp ratios than the dermis. The results are thus consistent with other observations (12) that 
bone collagen is the major source of urinary collagen degradation products and that skin collagen contributes little. A rapidly turning over component such as $\mathrm{Clq}_{\mathrm{q}}$ could be a major contributor when the magnitude of bone degradation becomes relatively less.

\section{ACKNOWLEDGMENTS}

We thank Rebecca Johnson for preparation of the manuscript.

This work was supported by U. S. Public Health Service grants AM-03564, AM-04501, and AM-05067, and a grant from the Massachusetts Chapter of the Arthritis Foundation.

\section{REFERENCES}

1. Prockop, D. J., and K. I. Kivirikko. 1968. Hydroxyproline and the metabolism of collagen. In Treatise on Collagen. B. S. Gould, editor. Academic Press, Inc., New York. 2A: 215-246.

2. Woessner, J. F., Jr. 1962. Catabolism of collagen and non-collagen protein in the rat uterus during postpartum involution. Biochem. J. 83: 304-314.

3. Weiss, P. H., and L. Klein. 1969. The quantitative relationship of urinary peptide hydroxyproline excretion to collagen degradation. J. Clin. Invest. 48: 1-10.

4. Efron, M. L., E. M. Bixby, and C. V. Pryles. 1965. Hydroxyprolinemia. II. A rare metabolic disease due to deficiency of the enzyme "hydroxyproline oxidase." N. Engl. J. Med. 272: 1299-1309.

5. Cunningham, L. W., J. D. Ford, and J. P. Segrest. 1967. The isolation of identical hydroxylysyl glycosides from hydrolysates of soluble collagen and from human urine. J. Biol. Chem. 242: 2570-2571.

6. Spiro, R. G. Characterization and quantitative determination of the hydroxylysine-linked carbohydrate units of several collagens. J. Biol. Chem. 244: 602-612.

7. Pinnell, S. R., R. Fox, and S. M. Krane. 1971. Human collagens: differences in glycosylated hydroxylysines in skin and bone. Biochim. Biophys. Acta. 229: 119-122.

8. Kakimoto, Y., and S. Akazawa. 1970. Isolation and identification of $N^{G}, N^{G_{-}}$and $N^{G}, N^{\prime} G_{\text {-dimethylarginine, }} N^{\epsilon}$-mono,di,- and trimethyllysine, and glucosylgalactosyl- and galactosyl $-^{-}$-hydroxylysine from human urine. J. Biol. Chem. 245: 5751-5758.

9. Segrest, J. P., and L. W. Cunningham. 1970. Variations in human urinary O-hydroxylysyl glycoside levels and their relationship to collagen metabolism. J. Clin. Invest. 49: $1497-1509$.

10. Smith, R., R. G. G. Russell, and M. Bishop. 1971. Diphosphonates and Paget's disease of bone. Lancet. 1: 945-947.

11. Singer, F. R., H. T. Keutmann, R. M. Neer, J. T. Potts, Jr., and S. M. Krane. 1972. Pharmacological effects of salmon calcitonin in man. In Calcium, Parthyroid Hormone and the Calcitonins. R. V. Talmage and P. L. Munson, editors. Excerpta Medica, Amsterdam. 89-96.

12. Pinnell, S. R., S. M. Krane, J. E. Kenzora, and M. J. Glimcher. 1972. A heritable disorder of connective tissue.
Hydroxylysine-deficient collagen disease. N. Engl. J. Med. 286: 1013-1020.

13. Staricco, R. J., and Pinkus, H. 1957. Quantitative and qualitative data on the pigment cells of adult human epidermis. J. Invest. Dermatol. 28: 33-45.

14. Miller, E. J., and K. A. Piez. 1966. An accelerated single-column procedure for the automatic analysis of amino acids in collagen and elastin hydrolyzates. Anal. Biochem. 16: 320-326.

15. Folin, O. 1914. On the determination of creatinine and creatine in urine. J. Biol. Chem. 17: 469-474.

16. Franck, W. A., N. M. Bress, F. R. Singer, and S. M. Krane. 1974. Rheumatic manifestations of Paget's disease of bone. Am. J. Med. 56: 592-603.

17. Moretti, G. F., L. Texier, and J. Staeffen. 1962. Elastorrhexie systématisée et maladie de Paget. Unité histologique des lésions du tissu elastique. Sem. Hop. Paris 38: 3813-3818.

18. Jeanloz, R. W., A. K. Bhattacharyya, and G. P. Roberts. 1969. The carbohydrate components of collagen. HoppeSeyler's Z. Physiol. Chem. 350: 663.

19. Spiro, R. G. 1973. Glycoproteins. Adv. Protein Chem. 27: 349-467.

20. Askenasi, R. 1974. Urinary hydroxylysine and hydroxylysyl glycoside excretions in normal and pathologic states. J. Lab. Clin. Med. 83: 673-679.

21. Hiles, R. A., and L. M. Henderson. 1972. The partial purification and properties of hydroxylysine kinase from rat liver. J. Biol. Chem. 247: 646-651.

22. Hammerstedt, R. H., P. B. Swan, and L. M. Henderson. 1968. Degradation of 5-hydroxylysine in the rat and in the perfused liver. Arch. Biochem. Biophys. 128: 243-251.

23. Miller, E. J. 1973. A review of biochemical studies on the genetically distinct collagens of the skeletal system. Clin. Orthop. 92: 260-280.

24. Kefalides, N. A. 1974. Biochemical properties of human glomerular basement membrane in normal and diabetic kidneys. J. Clin. Invest. 53: 403-407.

25. Yonemasu, K., R. M. Stroud, W. Niedermeier, and W. T. Butler. 1971. Chemical studies on Clq: a modulator of immunoglobulin biology. Biochem. Biophys. Res. Commun. 43: 1388-1394.

26. Calcott, M. A., and H. J. Müller-Eberhard. 1972. Clq protein of human complement. Biochemistry. 11: 34433450 .

27. Reid, K. B. M., D. M. Lowe, and R. R. Porter. 1972. Isolation and characterization of Clq, a subcomponent of the first component of complement, from human and rabbit sera. Biochem. J. 130: 749-763.

28. Reid, K. B. M. 1974. A collagen-like amino acid sequence in a polypeptide chain of human Clq (a subcomponent of the first component of complement). Biochem. J. 141: 189-203.

29. Kohler, P. F., and J. H. Müller-Eberhard. 1972. Metabolism of Clq. Studies in hypogammaglobulinemia, myeloma, and systemic lupus erythematosus. J. Clin. Invest. 51: 868-875.

30. Krane, S. M., A. J. Muñoz, and E. D. Harris, Jr. 1970. Urinary polypeptides related to collagen synthesis. J. Clin. Invest. 49: 716-729. 